\title{
Guru Honorer dalam Upaya Memperoleh Status Kepegawaian Tenaga Pendidik Pegawai Negeri Sipil
}

\author{
Nurdin \\ PGPAUD, Universitas Terbuka \\ e-mail : nurdin@ecampus.ut.ac.id
}

\begin{abstract}
ABSTRAK. Pendidikan anak usia dini merupakan lembaga pendidikan pertama yang dilalui oleh anak. Pendidikan pada masa ini merupakan periode penting bagi perkembangan anak dimasa depan. Pendidikan anak usaia dini bisa dilakukan melalui lembaga formal, non formal ataupun informal. Pendidikan bisa dilakukan dengan baik apabila semua pihak yang terlibat dalam proses pendidikan bisa menjalankan tugas dan tanggungjawab secara profesional. Salah satu instrument penting dalam pendidikan anak usia dini adalah guru, yang berkewajiban untuk mendidik, mengajar, membimbing, mengarahkan, melatih, menilai serta mengevaluasi perserta didik pada pendidikan anak usia dini jalur pendidikan formal, pendidikan dasar serta pendidikan menengah. Status kepegawaian yang dimiliki oleh guru terdiri dari guru pegawai negeri dan guru non pegawai negeri atau dikenal sebagai tenaga honorer. Terdapat perbedaan hak yang diterima oleh tenaga pendidik PNS dengan tenaga pendidik honorer. Walaupun hak yang diterima berbeda akan tetapi tanggung jawab yang dijalankan tetap sama. Hal ini memberikan perbedaan yang besar antara guru PNS dan tenaga honorer. Oleh karena itu tenaga honorer melakukan berbagai upaya untuk merubah status kepegawaian menjadi guru PNS. Akan tetapi terdapat hambatan yang dilalui oleh tenaga honorer untuk mewujudkan tujuan tersebut, diantaranya adalah tidak tersedianya jalur khusus untuk mendapatkan status PNS dengan memanfaatkan status honorer sebelumnya. Belum tersedianya regulasi atau aturan yang mengatur mengenai pengangkatan tenaga honorer menjadi CPNS, kemampuan keuangan pemerintah pusat dan daerah yang masih rendah, belum bisa mengakomodasi pengangkatan guru honorer menjadi CPNS
\end{abstract}

Kata Kunci : Guru Honorer; Status Kepegawaian; Pendidik PAUD

ABSTRACT. Early childhood education is the first educational institution that children go through. Education at this time is an important period for the development of children in the future. Early childhood education can be done through formal, non-formal or informal institutions. Education can be carried out properly if all parties involved in the educational process can carry out their duties and responsibilities professionally. One of the important instruments in early childhood education is the teacher, who is obliged to educate, teach, guide, direct, train, assess, and evaluate students in early childhood education through formal education, basic education, and secondary education. The staffing status of teachers consists of civil servant teachers and non-civil servant teachers or known as honorary staff. There are differences in the rights received by civil servant educators and honorary educators. Although the rights received are different, the responsibilities that are carried out remain the same. This makes a big difference between PNS teachers and honorary staff. Therefore, the honorary staff made various efforts to change the status of the employee to become a civil servant teacher. However, there are obstacles that are traversed by honorary staff to achieve this goal, including the 
unavailability of a special route to obtain civil servant status by utilizing the previous honorary status. The unavailability of regulations or rules governing the appointment of honorary staff to become CPNS, the financial capacity of the central and regional governments is still low, unable to accommodate the appointment of honorary teachers to become CPNS

Keyword : Honorary teacher; Employment status; PAUD Educator

\section{PENDAHULUAN}

Sumber daya manusia menjadi salah satu aspek penting dalam proses perkembangan dan pembangunan negara. Oleh karena itu kualitas dari sumber daya manusia yang dimiliki oleh suatu negara harus diperhatikan serta sesuai dengan kebutuhan perkembangan zaman. Sumber daya manusia yang berkualitas bisa dibangun melalui proses pendidikan. Selain itu proses pendidikan yang dijalankan oleh seseorang merupakan salah satu upaya untuk mengembangkan potensi yan dimilikinya. Berdasarkan Undang-Undang No, 20 Tahun 2003 tentang Sistem Pendidikan Nasional menyatakan bahwa pendidikan dijalankan melalui tiga jalur yaitu: pendidikan formal, pendidikan non formal serta pendidikan informal. Standar umum pendidikan yang berkembang di tengah masyarakat adalah pendidikan formal.

Pendidikan formal yang wajib diikuti oleh warga negara Indonesia adalah jenjang penidikan Sekolah Dasar (SD), Sekolah Menengah Pertama (SMP) dan Sekolah Menengah Atas (SMA). Fungsi dan tujuan pendidikan nasional yang tertuang dalam Undang-Undang No. 20 Tahun 2003 pasal 3 mengamanatkan bahwa fungsi dari pendidikan nasional yaitu mengembangkan kemampuan dan membentuk watak serta peradaban bangsa yang bermartabat dalam rangka mencerdaskan kehidupan bangsa. Sedangkan tujuan dari pelaksanaan pendidikan nasional adalah untuk mengembangkan potensi yang dimiliki oleh peserta didik agar menjadi manusia yang beriman dan bertakwa kepada Tuhan Yang Maha Esa, berakhlak mulia, sehat, berilmu, cakap, kreatif, mandiri, dan menjadi warga negara yang demokratis serta bertanggung jawab.

Pendidikan yang diterima oleh seseorang dimulai semenjak dilahirkan. Menurut Zaini[1], pendidikan yang dijalankan oleh seorang anak sejak usia dini memiliki peranan penting dalam membantu perkembangan potensi serta karakteristik anak pada masa yang akan datang. Anak usia dini digolongkan kedalam anak usia pra sekolah yang pertumbuhannya terbagi kedalam dua tahap, yakni: pada usia 0-2 tahun pertumbuhan anak lebih mengarah kepada fungsi-fungsi biologis. Sedangkan tahap kedua adalah pada usia 2-6 tahun, dimana pada usia tersebut perkembangan panca indera yang sangat menonjol. Pendidikan anak usia dini menjadi hal penting karena pada saat anak berusia 0-4 tahun kapabilitas kecerdasan yang dimiliki anak mencapai 50\%, pada usia 4-8 tahun mencapai $80 \%$ sedangkan diatas 8 tahun kapabilitas yang dimiliki anak yaitu 20\%. Oleh karena itu orang tua harus memperhatikan penyelenggaraan pendidikan pendidikan anak pada usia dini. Salah satu upaya yang bisa dilakukan oleh orang tua untuk mengoptimalkan pendidikan yang diterima anak pada usia ini adalah melalui lembaga Pendidikan Anak Usia Dini (PAUD). 
Namun persoalan yang dihadapi oleh banyak lembaga pendidikan anak usia dini terkusus lembaga pendidikan yang dikelola oleh yayasan-yayasan tertentu adalah rendahnya tingkat kesejahteraan para tenaga pengajar atau guru-guru honorer. Sementara, para guru yayasan atau tenaga honorer ini harus mendidik para generasi anak bangsa yang menempuh pendidikan di jenjang pertama, yakni Pendidikan Anak Usia Dini. Di lain sisi mereka para guru PAUD juga berjibaku memenuhi kebutuhan hidup mereka, sementara tingkat kesejahteraan yang mereka terima sangatlah minim.

Selama ini, peran para guru honorer untuk memajukan pendidikan sudah cukup besar. Meski demikian, kesejahteraan yang dirasakakan belum begitu maksimal. Mereka semua adalah pihak yang harus diperjuangkan, karena di lapangan para tenaga honorer ini sangat perlu perhatian serius. Dimana begitu banyak fakta-fakta bahwa guru honorer di PAUD hanya menerima honor Rp.300.000 / bulan.

Dalam prakteknya, peran lembaga pendidikan dan sekolah swasta di bawah yayasan misalnya, sudah sangat luar biasa dan cukup besar dampaknya dalam mencerdaskan kehidupan bangsa. Meski pemerintah sudah menyalurkan dana BOS, tetapi kesejahteraan mereka menjadi catatan penting untuk diperjuangkan. Dampak jangka panjang dari minimnya kesejahteraan ini jika tidak segera ditanggapi dan dibiarkan secara terus menerus, dikhawatirkan akan mempengaruhi semangat para guru dan tenaga honorer ini, dan pada akhirnya bisa berdampak pada proses belajar mengajar.

Pada prinsipnya, insentif bagi guru swasta dan yayasan perlu dipikirkan secara bersama-sama, tentu dengan besaran nilai tertentu yang dianggap layak untuk diterima. Perjuangan ini tentu saja bukan dengan menaikan jumlah bayaran sekolah, akan tetapi perjuangan yang lebih memungkinkan adalah menghadirkan regulasi yang memihak kepada para tenaga honorer di sekolah-sekolah swasta. Bisa saja di mulai secara bertahap, dari para guru PAUD, kemudian selanjutnya SD dan sampai tingkat pendidikan teratas.

Secara teori, ketika tingkat kesejahteraan terpenuhi kebutuhannya, maka tentu akan berdampak positif. Bahkan akan berbanding lurus dengan kualitas pendidikan yang semakin meningkat. Guru bisa lebih konsentrasi dan hanya memikirkan terkait dengan proses belajar mengajar semata. Selama ini, para kepala sekolah atau ketuaketua yayasan masih memikirkan berbagai hal tentang kebutuhan untuk menunjang KBM, dan para gurunya juga sibuk memikirkan bagaimana tentang kesejahteraan masing-masing. Persoalan guru-guru honorer ini jika dibiarkan tentu akan menghambat proses pendidikan itu sendiri. Sementara, berdasarkan Peraturan Pemerintah No. 48 tahun 2005, tenaga honorer adalah seseorang yang diangkat oleh pejabat Pembina kepegawaian atau pejabat lain dalam pemerintahan untuk melaksanakan tugas tertentu pada instansi pemerintah atau yang penghasilannya menjadi beban dalam Anggaran Pendapatan dan Belanja Negara (APBN) ataupun Anggaran Pendapatan dan Belanja Daerah (APBD). Sedangkan guru honorer adalah tenaga pendidik yang diangkat oleh kepala sekolah untuk mengajar di sekolah dengan honor yang didapatkan bersumber dari dana Bantuan Operasional Sekolah (BOS). 
Secara umum beban tugas yang dimiliki oleh tenaga pendidik yang berstatus PNS ataupun tenaga pendidik honorer adalah sama. Namun perbedaan status kepegawaian antara PNS dan tenaga honorer menyebabkan kompensasi yang diperoleh berbeda. PAUD menjadi salah satu jenjang pendidikan di Indonesia dengan tenaga pendidik yang memiliki status sebagai PNS dan juga tenaga pendidik honorer. Namun, kompensasi yang terima oleh guru honorer PAUD masih terbilang minim dan memprihatinkan jika dibandingkan dengan beban kerja serta tanggung jawabnya.

Sebagain guru non-PNS menerima kompensasi sebesar Rp.100.000-200.000 tiap bulannya dengan intensitas mengajar 3-5 kali dalam sepekan. Seperti yang telah dijelaskan di atasm bahwa kompensasi yang diterima oleh tenaga pendidik ini tentu akan berpengaruh kepada kinerja mereka dalam proses belajar mengajar. Kompensasi yang kecil menyebabkan guru honorer kurang fokus dalam melakukakn pekerjannya, bisa jadi penyebabnya adalah guru tersebut memiliki pekerjaan lain diluar tanggung jawab sebagai guru untuk mencukupi kebutuhannya [2].

Pendapatan yang diterima oleh seseorang akan mempengaruhi tingkat kesejahteraanya. Besaran kompensasi yang diterima oleh guru honorer masih terbilang sangat kecil jika dibandingkan dengan tanggung jawab yang dijalankan. Permasalahan tersebut menyebabkan timbulnya tuntutan dari guru honorer agar pemerintah menetapkan upaya-upaya untuk meningkatkan kesejahteraan dari guru honorer. Menurut Sunandar, demonstrasi yang dilakukan oleh guru honorer merupakan cerminan permasalahan mendasar dalam manajerial pendidikan dan pengelolaan sumber daya guru. Permasalahan tersebut diantaranya terkait dengan permasalahan kesejahteraan. Hal ini menjadi pemicu sebagian besar guru honorer memilih melakukan demostrasi untuk menyuarakan tuntutannya[3].

Berdasarkan latar belakang tersebut maka tujuan dari tulisan ini adalah untuk melihat bagaimana hambatan serta upaya yang dilakukan oleh guru honorer PAUD untuk meningkatkan kesejahteraannya melalui permohonan untuk meningkatkan kesejahteraan mereka dengan kenaikan insentif dan bahkan permohonan untuk pengangkatan sebagai tenaga PNS. Selain itu juga untuk mengetahui apa saja hambatanhambatan yang dilalui guru honorer untuk meningkatkan kesejahteraanya, serta upaya yang dilakukan agar status kepegawaiannya berubah dari guru honorer menjadi tenaga pendidik PNS.

\section{METODE}

Penelitian ini berbeda dari penelitian yang memungkinkan peneliti untuk turun langsung ke lapangan, tetapi bersumber dari sumber-sumber yang ada, disebut dengan penelitian kepustakaan atau library research. Sebuah penelitian dengan metode pengumpulan menggunakan data pustaka, yang bertujuan untuk menyatukan data dan informasi dengan berbagai macam sumber di perpustakaan. Seperti buku, jurnal atau artikel (online), serta sejarah dan lainnya. Jadi, metode yang digunakan penulis tidak langsung menggunakan metode yang seharusnya terjun ke lapangan, tetapi dari sumber-sumber yang ada. Seperti buku, jurnal maupun dokumen-dokumen baik cetak maupun elektronik yang relevan [4]. 


\section{HASIL DAN PEMBAHASAN}

\section{A. Pendidikan Anak Usia Dini (PAUD)}

Pendidikan Anak Usia dini adalah proses pembinaan perkembangan anak sejak lahir sampai dengan usia 6 tahun. Pendidikan dijalankan secara menyeluruh terhadap semua aspek perkembangan dengan memberikan rangsangan terhadap perkembangan rohani serta jasmani dengan tujuan agar proses perkembangan anak bisa berjalan secara optimal[1]. Prinsip-prinsip penyelenggaraan pendidikan anak usia dini menurut Sayudi dan Maulidya[5] adalah: Pendidikan pada masa anak- anak dijalankan untuk pengoptimalkan potensi yang dimiliki anak secara optimal. Perkembangan seluruh aspek yang dimilu oleh anak menjadi hal yang penting dalam pelaksanaan pendidikan anak usia dini baik aspek fisik, mental, kesehatan, cara berfikir serta aspek psikis. Pembelajaran pada anak usia dini dilakukan melalui kegiatan yang saling terkait antara satu sama lain. Pendidikan anak usia dini memiliki peranan yang penting untuk memotivasi perkembangan dari dalam diri anak. Program pendidikan anak usia dini ditekankan pada sikap disiplin anak untuk membantu pembentukan watak serta kepribadian anak dimasa depan. Pada usia 0 - 3 tahun merupakan masa peka pada anak sehingga diperlukan obseravasi yang lebih detail untuk membangun perencanaan pembelajaran pendidikan anak usia dini. Tolak ukur dalam penilaian pendidikan anak usia dini adalah kegiatan yang mampu untuk dikerjakan anak bukan mengajarkan halhal baru pada anak. Kondisi terbaik terjadi dalam diri anak (innerlife) khususnya apabila kondisinya menunjang. Linkungan sekitar anak merupakan faktor penting dalam perkembangan anak. Pendidikan anak usia dini pada dasarnya merupakan interaksi yang terjadi antara anak dan lingkungan, orang dewasa serta pengetahuan.

Proses pelaksanaan pendidikan di lembaga sekolah di Indonesia melibatkan banyak pihak. Guru yang berperan sebagai tenaga pendidik menjadi instrument utama dalam pelaksanaan pendidikan di sekolah. Guru merupakan pendidik profesional yang memiliki tugas utama yaitu mendidik, mengajar, membimbing, mengarahkan, melatih, menilai serta mengevaluasi perserta didik pada pendidikan anak usia dini jalur pendidikan formal, pendidikan dasar serta pendidikan menengah[6]. Kompetensi Guru mendesain dan membuat media pembelajaran masih rendah karena kurangnya pengetahuan dan ketrampilan yang dimiliki. Pelatihan pembuatan media dengan pemanfaatan barang bekas telah memberikan kesadaran kritis bagi komunitas dampingan akan pentingnya variasi media pembelajaran dengan prinsip Belajar Melalui Bermain dan mempertimbangkan berbagai aspek perkembangan anak usia dini[7]. Kualitas yang dimiliki oleh seoarang tenaga pendidik mempengaruhi kualitas pendidikan yang diberikan pada lembaga pendidikan.

Guru merupakan pegawai pemerintah yang berada di bawah nungan Departemen Pendidikan Nasional (Depdiknas). Berdasarkan hal tersebut, maka segala hal mengenai profesi guru telah diamanatkan dalam undang-undang, termasuk didalamnya mengenai status kepegawaian, pendapatan serta hal lainnya. Status kepegawaian yang dimiliki oleh seorang guru dibagi menjadi pegawai negeri dan non pegawai negeri. Berdasarkan UU No. 43 Tahun 1999, pegawai negeri didefinisikan sebagai setiap warga negara 
Republik Indonesia yang memenuhi syarat tertentu atau diserahi tugas negara lainnya serta digaji berdasarkan peraturan perundang - undangan yang berlaku. Namun, tidak semua guru memiliki status kepegawaian sebagai pegawai negeri, terdapat guru yang memiliki status non pegawai negeri salah satunya adalah guru honorer. Guru honorer merupakan tenaga pendidik yang diangkat oleh kepala sekolah untuk mengajar di sekolah dengan honor yang diperolah dari dana Bantuan Operasional Sekolah (BOS). Walaupun memiliki status kepegawaian yang dimiliki oleh guru berbeda-beda, tetapi tugas dan tanggungjawab sebagai tenaga pendidik adalah sama.

Tenaga pendidik pada lembaga Pendidikan Anak Usia Dini (PAUD) membutuhkan komitmen, kesungguhan serta kesabaran. Tenaga pendidik menurut Permendikbud No. 137 Tahun 2014 dan Permendiknas No. 58 Tahun 2009 mempunyai persamaan, di antaranya: 1. Untuk menjadi guru PAUD harus memiliki ijazah Diploma empat (D-IV) atau Sarjana (S1) dalam bidang pendidikan anak usia dini yang diperoleh dari program studi terakreditasi, atau sarjana kependidikan lain yang relevan (psikologi) dan memiliki sertifikat Pendidikan Profesi Guru (PPG). Selain itu, guru PAUD harus memeliki empat kompetensi dasar, yaitu kompetensi pedagogi, kepribadian, sosial dan professional [8]. Hal ini dikarenakan anak usia dini yang menjadi tanggung jawab tenaga pendidik memiliki karakteristik yang beragam sehingga membutuhkan penanganan yang khusus. Seorang tenaga pendidik pada lembaga PAUD harus memahami tahap perkembangan yang dilalui oleh anak usia dini, serta harus menguasai metode pembelajaran dengan memperhatikan prinsip saintifik dan menyusun evaluasi tiap tiap anak berdasarkan pada capaian perkembangan secara berkala. Selain itu, tenaga pendidik pada lembaga PAUD juga perlu menjalin hubungan yang baik dengan orang tua peserta didik, rekan kerja serta pengelola sekolah sehingga tercipta lingkungan sosial yang mendukung perkembangan anak usia dini. Kinerja mengajar guru PAUD di kota serang pada masa pandemic covid 19 sangat baik, para guru berupaya memberikan pelayanan yang prima kepada peserta didik dengan mempertahankan atau bahkan meningkatkan kompetensi mereka dalam upaya menyelenggarakan pendidikan yang bermutu. Optimalisasi kinerja guru dilihat dari bagaimana guru mempersiapkan diri baik sarana maupun prasarana dalam menyelenggarakan pembelajaran dari rumah tersebut[9].

Tanggung jawab yang dimiliki oleh tenaga pendidik pada lembaga PAUD harus dijalankan dengan baik serta profesional. Namun, perbedaan status kepegawaian yang dimiliki oleh tenaga pendidik mempengaruhi kinerja daari tenaga pendidik. Seperti yang ditemukan dalam penelitian Ulfah et al yang menyatakan bahwa kompensasi yang diterima oleh tenaga pendidik pada PAUD mempengaruhi tingkat profesionalisme tenaga pendidik secara positif. Kesimpulan ini dapat diinterpretasikan bahawa, semakin tinggi kompensasi yang diterima oleh seorang tenaga pendidik PAUD, maka profesionalisema guru PAUD juga akan meningkat[10]. 


\section{B. Hambatan yang Dilalui oleh Guru Honorer Lembaga Pendidikan Anak Usia Dini (PAUD)}

Di Indonesia jumlah guru menurut data Kemendikbud ada sebanyak 3.015.315 guru. Dari jumlah itu, sebanyak 2.294.191 guru berstatus PNS dan guru tetap yayasan (GTY). Sedangkan sisanya sebanyak 721.124 guru berstatus guru tidak tetap (GTT) dan tidak bersertifikasi.(Kedaulatan Rakyat, 11 Januari 2016). Dari 3 (tiga) juta guru tersebut tidak sedikit yang masih bermasalah, baik dari segi profesionalisme, insentif bahkan terkait kepribadian[11].

Pada kenyataanya, secara terang benderang kita bisa melihat adanya ketimpangan kesejahteraan yang sangat signifikan antara guru PNS dengan guru honor yang membuat kecemburuan sosial. Kondisi ini pada akhirnya tentu saja mempengaruhui niat para guru, sehingga luntur pengabdian akibat minimnya kesejahteraan yang diterima mereka, terutama guru tidak tetap atau guru honor. Dengan pendapatan minim, mereka kurang antusias dalam mengajar, sehingga kurang menikmati profesinya yang membuat mereka jadi tidak profesional. Persoalan mereka kenyataanya bukan itu saja, ada kelebihan beban mengajar akibat minimnya jumlah guru, terutama guru-guru di daerah tertinggal. Mereka juga banyak yang belum memenuhi kualifikasi standar sebagai seorang pendidik dan mengajar bukan di bidang keahliannya[12].

Cukup banyak penelitian yang mengambarkan permasalahan-permasalahan pendidikan di Indonesia. Dari segi profesionalisme, para guru sendiri banyak yang tidak paham. Belum lagi persoalan insentif, gaji dan tunjungan yang mereka terima. Sehingga pada akhirnya begitu sangat jelas terlihat kesenjangan antara kebijakan pemerintah dengan realitas di lapangan. Guru ideal yang diharapkan bisa bermunculan pasca berlakunya UU No. 14 Tahun 2005, namun pada kenyataannya sulit terwujud. Problematika tersebut tentu saja tidak lahir secara instan. Jika akan mengukur kualitas dan kompetensi guru, tentu tidak dapat dilepaskan dari lembaga pendidikan yang melahirkan guru itu sendiri. Terlepas dari itu semua, kenyataan di lapangan bahwa para tenaga guru honorer khususnya, baik yang yayasan ataupun negeri masih berjuang untuk kesehteraan dan status kepegawaian mereka. Status kepegawaian yang dimiliki oleh tenaga pendidik terdiri dari guru PNS dan non pegawai negeri atau dikenal dengan tenaga honorer[13].

Berdasarkan Peraturan Pemerintah No. 48 Tahun 2005, tenaga honorer merupakan seseorang yang diangkat oleh pejabat Pembina kepegawaian atau pejabat lain dalam pemerintahan untuk melaksanakan tugas tertentu pada instansi pemerintah atau yang pengahsilannya menjadi beban Anggaran Pendapatan dan Belanja Negara (APBN) atau Anggaran Pendapatan dan Belanja Daerah (APBD). Sedangkan guru honorer adalah guru yang diangkat oleh kepala sekolah atau lembaga pendidikan lain untuk mengajar di sekolah dengan honor yang didapatkan dari dana Bantuan Operasional Sekolah (BOS).

Perbedaan status kepegawaian yang dimiliki oleh tenaga pendidik menyebabkan hak yang diperoleh juga akan berbeda, meskipun tanggung jawab dan kewajiban yang dimiliki sama yaitu mengajar dan mendidik siswa. Undang-Undang No. 8 Tahun 1974, 
mengamanatkan hak yang didapatkan oleh pegawai negeri diantaranya adalah hak mendapatkan gaji yang layak sesuai dengan pekerjaan dan tanggung jawab, hak atas cuti, hak memperoleh perawatan jika ditimpa suatu kecelakaan saat menjalankan tugas, hak memperoleh tunjangan jika menderita cacat jasmani atau rohani karena menjalankan tugasnya serta hak mendapatkan tunjangan kematian jika pegawai yang bersangkutan meninggal dunia[14]. Sedangkan untuk tenaga honorer tidak memperoleh hak demikian. Pemberian kompensasi bagi tenaga honorer diperoleh dari dana Bantuan Operasional Sekolah (BOS) dengan mempertimbangkan rasio jumlah siswa dan guru seseuai dengan ketentuan pemerintah dalam Peraturan Menteri Pendidikan No. 15 Tahun 2010.

Perbedaan kesejahteraan antara tenaga pendidik honorer dengan pegawai status PNS, meningkatkan motivasi guru honorer untuk memperoleh hak yang sama dengan tenaga pendidik PNS. Hal ini juga dikemukakan oleh Megawanti dalam penelitiannya yang menerangkan bahwa, salah satu hambatan atau permasalahan yang dilalui oleh guru honorer adalah tidak sebandingnya antara kompensasi yang diterima oleh guru honorer dengan tanggung jawab yang dibebankan serta tuntutan profesional yang harus dijalankan oleh guru honorer[15]. Rousseau dalam Ulfah et al menjelaskan bahwa usia dini merupakan masa yang fundamental untuk perkembangan anak. Pendidikan yang diperoleh oleh anak pada usia tersebut berpengaruh terhadap perkembangan anak hingga dewasa, artinya tanggungjawab yang dimiliki oleh tanaga pendidik PAUD sangat penting untuk perkembangan peserta didik[10]. Tanggungjawab yang dimiliki oleh guru PAUD harus diiringi dengan penerimaan kompensasi yang layak[2].

Berdasarkan data survey mengenai gaji ideal yang diterima oleh guru bulanna yang dilakukan oleh Federasi Guru Independen Indonesia (FGII) pada tahun 2015 ditemukan bahwa nilainya sebegar Rp. 3.000.000. Namun, data yang diperoleh dari survey yang dilakukan ditemukan bahwa pendapatan rata rata guru bantu Rp. 460.000 per bulan, sedangkan guru honorer di sekolah swasta menerima pendapatan sebesar Rp. $10.000 /$ jam. Kompensasi minim yang diterima oleh guru honorer menjadi alasan yang mendorong guru honorer melakukan upaya upaya tertentu untuk memperoleh status sebagai guru pegawai negeri.

Upaya yang dilakukan oleh guru honorer untuk memperoleh status kepegawaian sebagai guru pegawai negeri, tujuannya secara individu adalah untuk meningkatkan kebahagiaan tenaga pendidik. Berdasarkan penelitian yang dilakukan oleh Setiyawan menjelaskan dalam penelitiannya bahwa terdapat perbedaan antara tingkat kebahagiaan yang sangat jelas dari guru yang berstatus PNS dengan guru non PNS. Hal ini disebabkan oleh perbedaan pendapatan yang diterima oleh guru PNS dan guru non PNS[16]. Pernyataan yang sama juga disampaikan oleh Ma dan Zhang bahwa pendapatan memiliki hubungan positif dengan kebahagiaan[17]. Kompensasi yang diterima oleh tenaga pendidik juga mempengaruhi kinerja guru, seperti dalam penelitian yang dilakukan oleh Ulfah et al yang menjelaskan bahwa kompensasi mempengaruhi secara signifikan terhadap profesionalisme guru[10].

Upaya yang dilakukan oleh guru honorer dalam mencapai status kepegawaian PNS masih menghadapi berbagai hambatan. Menurut Tengku Imam Kobul Moh Yahya S 
yang menjabat sebagai Direktur Sosial dan Pendidikan, Lembaga Swadaya Maysarakat (LSM), menyampaikan bahwa terdapat 5 kendala pemerintah untuk mengangkat guru honorer menjadi Calon Pegawai Negeri Sipil (CPNS) yaitu: Belum tersedianya regulasi atau aturan yang mengatur mengenai pengangkatan tenaga honorer menjadi CPNS. Kemampuan keuangan pemerintah belum bisa mengakomodasi pengangkatan guru honorer menjadi CPNS. Guru merupakan pagawai daerah, sehingga pengangkatan guru honorer menjadi CPNS belum bisa dimaksimalkan, salah satu penyebabnya adalah perbedaan kemampuan anggaran serta aturan prioritas pembangunan yang dimiliki oleh daerah. Kualifikasi pendidikan, dimana masih banyak ditemukan tenaga pendidik yang tidak linear dengan tugas yang menjadi tanggungjawabnya. Belum adanya komitmen dari pemerintah untuk mengangkat guru honorer menjadi tenaga CPNS[18].

\section{KESIMPULAN}

Upaya yang dilakukan oleh guru honorer dalam mencapai status kepegawaian PNS masih menghadapi berbagai hambatan. Karena ada 5 kendala pemerintah untuk mengangkat guru honorer menjadi Calon Pegawai Negeri Sipil (CPNS) yaitu: Belum tersedianya regulasi atau aturan yang mengatur mengenai pengangkatan tenaga honorer menjadi CPNS. Kemampuan keuangan pemerintah belum bisa mengakomodasi pengangkatan guru honorer menjadi CPNS. Guru merupakan pagawai daerah, sehingga pengangkatan guru honorer menjadi CPNS belum bisa dimaksimalkan, salah satu penyebabnya adalah perbedaan kemampuan anggaran serta aturan prioritas pembangunan yang dimiliki oleh daerah. Kualifikasi pendidikan, dimana masih banyak ditemukan tenaga pendidik yang tidak linear dengan tugas yang menjadi tanggungjawabnya. Belum adanya komitmen dari pemerintah untuk mengangkat guru honorer menjadi tenaga CPNS.

\section{PENGHARGAAN}

Terima kasih penulis ucapkan kepada semua pihak yang terlibat dan membantu terlaksananya penelitian ini. Tidak lupa diucapan terima kasih kepada editor dan reviewer Jurnal Murhum yang sudah memberikan kesempatan sehingga jurnal bisa untuk dipublish/diterbitkan.

\section{REFERENSI}

[1] A. Zaini, "Bermain sebagai Metode Pembelajaran bagi Anak Usia Dini," ThufuLA J. Inov. Pendidik. Guru Raudhatul Athfal, vol. 3, no. 1, p. 118, Jan. 2019, doi: 10.21043/thufula.v3i1.4656.

[2] J. T. Seyfarth, Human resources management for effective schools. ERIC, 2002.

[3] A. Sunandar, "Sistem Rekrutmen dan Manajerial Kompetensi Guru Honorer," Univ. Negeri Malang, 2014.

[4] Supriyadi, "Community of Practitioners: Solusi Alternatif Berbagi Pengetahuan antar Pustakawan," Lentera Pustaka J. Kaji. Ilmu Perpustakaan, Inf. dan Kearsipan, vol. 2, no. 2, pp. 83-93, 2016, doi: 10.14710/lenpust.v2i2.13476.

[5] K. Maryani, "Penilaian dan Pelaporan Perkembangan Anak Saat Pembelajaran di 
Rumah di Masa Pendemi Covid-19," Murhum J. Pendidik. Anak Usia Dini, vol. 1, no. 1, pp. 41-52, 2020, doi: 10.37985/murhum.v1i1.4.

[6] D. S. Winarni, "Analisis Kesulitan Guru PAUD dalam Membelajarakan IPA pada Anak Usia Dini," Edu Sains J. Pendidik. Sains Mat., vol. 5, no. 1, p. 12, Aug. 2017, doi: 10.23971/eds.v5i1.578.

[7] E. Erdiyanti and S. Syukri, "Peningkatan Kompetensi Guru PAUD Non PG-PAUD Melalui Pendampingan Pembuatan Media Pembelajaran Di Kecamatan Konda," Murhum J. Pendidik. Anak Usia Dini, pp. 68-79, Jun. 2021, doi: 10.37985/murhum.v2i1.34.

[8] L. O. Anhusadar and I. Islamiyah, "Kualifikasi Pendidik PAUD Sesuai Permendikbud Nomor 137 Tahun 2014," J. Early Child. Educ. Res., vol. 1, no. 2, pp. 55-61, Mar. 2020, doi: 10.37985/joecher.v1i2.8.

[9] R. M. Raharja, R. D. Kusuma Wardhani, and L. Rosidah, "Kinerja Guru PAUD di Kota Serang pada Masa Pandemi Covid 19," Murhum J. Pendidik. Anak Usia Dini, no. 1, pp. 13-22, Feb. 2021, doi: 10.37985/murhum.v2i1.28.

[10] C. Ulfah, Y. Yuliejantiningsih, and S. Soegeng, "PENGARUH KOMPENSASI DAN MOTIVASI KERJA TERHADAP PROFESIONALISME GURU PAUD DI KECAMATAN UNGARAN BARAT KABUPATEN SEMARANG," J. Manaj. Pendidik., vol. 5, no. 2, Dec. 2017, doi: 10.26877/jmp.v5i2.1935.

[11] D. Ru'ung, "PENGUATAN TENAGA PENDIDIK: UPAYA MEMINIMALISIR PROBLEMATIKA PENDIDIKAN NASIONAL," J. LENTERA Kaji. Keagamaan, Keilmuan Dan Teknol., vol. 20, no. 01, pp. 130-145, 2021.

[12] M. Rohman, "Problematika Guru dan Dosen dalam Sistem Pendidikan di Indonesia," Cendekia J. Educ. Soc., vol. 14, no. 1, p. 49, Jun. 2016, doi: 10.21154/cendekia.v14i1.616.

[13] A. D. Hardiyanto, "Pengangkatan Tenaga Honorer Menjadi Calon Pegawai Negeri Sipil Di Era Otonomi Daerah (Studi pada Badan Kepegawaian Daerah Kota Batu)," J. Adm. Publik, vol. 1, no. 3, pp. 34-41, 2013.

[14] D. K. WULAN and N. SARI, "REGULASI EMOSI DAN BURNOUT PADA GURU HONORER SEKOLAH DASAR SWASTA MENENGAH KE BAWAH," JPPP - J. Penelit. dan Pengukuran Psikol., vol. 4, no. 2, pp. 74-82, Oct. 2015, doi: 10.21009/JPPP.042.05.

[15] P. Megawanti, "Hubungan Budaya Organisasi Dan Kepuasan Kerja Dengan Komitmen Organisasi Guru Honorer," Sosio e-kons, vol. 6, no. 1, 2017, doi: 10.30998/sosioekons.v6i1.1713.

[16] D. P. Setiyawan, "PERBEDAAN KEBAHAGIAAN GURU DI TINJAU DARI STATUS GURU PNS DAN NON PNS (HONORER)," University of Muhammadiyah Malang, 2017.

[17] Y. Z. Ma and Y. Zhang, "Resolution of the Happiness-Income Paradox," Soc. Indic. Res., vol. 119, no. 2, pp. 705-721, Nov. 2014, doi: 10.1007/s11205-013-0502-9.

[18] Tengku Imam Kobul Moh Yahya S, "5 Kendala Pengangkatan Guru Honorer Menjadi CPNS Tahun 2018," https://bangimam-berbagi.blogspot.com/, 2018. https://bangimam-berbagi.blogspot.com/2018/04/5-kendala-pengangkatanguru-honorer.html. 